\title{
Entrepreneurial Culture and Organizational Climate in the Barbers Village, Garut, Indonesia
}

\author{
Galih Abdul Fatah Maulani*, Nizar Alam Hamdani, Sukma Nugraha, Teten Mohamad Sapril Mubarok \\ Universitas Garut \\ Garut, Indonesia \\ *galihafm@uniga.ac.id
}

\begin{abstract}
As the city of dodol, Garut is also famous for its most excellent barbers. A lot of barbers in Indonesia originate from this city, precisely from a village called Kampung Parung, Banyuresmi Subdistrict. After finishing high schools, most teenagers from the village go to big cities to start barbershop businesses instead of joining universities. Some open their barbershops in Garut and its surrounding area. In general, barbershop has been a long-established entrepreneurial culture in the village. The purpose of this study therefore is to determine how entrepreneurial culture is established and how it affects the organizational climate of barbershop business. A survey was conducted with 77 barbers in Garut, and the results show that family and economy have a significant influence on the entrepreneurial culture. Additionally, entrepreneurial culture positively contributes to the establishment of an organizational climate of barbershop business. Education is not considered to be of much importance to the Garutian barbers.
\end{abstract}

Keywords - entrepreneurial culture, organizational climate, village of the barbers, Garut

\section{INTRODUCTION}

Entrepreneurship is one of the main factors that stimulate economic development and plays a vital role in developing countries in various aspects [1,2]. In the process of development, entrepreneurship is supported by people with an entrepreneurial culture that is formed naturally or unnaturally [3]. In dealing with Industrial Revolution 4.0, both developed and developing countries are supposed to increase their competitiveness in international trading. This requires an excellent understanding of the entrepreneurial culture that needs to be established in today's society [4-6]. Entrepreneurs are often used as indicators to determine whether a country is developed. The minimum standard ratio of entrepreneurs is supposed to be $2 \%$ of the total population [7]. In Indonesia, there is a constant growth of entrepreneurship every year, can be seen on table 1 .

TABLE I. INDONESIA ENTREPRENEURSHIP RATIO [8]

\begin{tabular}{|c|c|c|}
\hline Year & $\mathbf{2 0 1 7}$ & $\mathbf{2 0 1 8}$ \\
\hline Entrepreneurship Ratio & $1.6 \%$ & $3.1 \%$ \\
\hline
\end{tabular}

From the data, Indonesia has passed the minimum rate of $2 \%$, indicating that the growth of entrepreneurship is positive. The government was even optimistic that the ratio could go beyond 5\% by the end of 2019 [9]. However, the country's achievement is not comparable to the neighboring such as Singapore (7\%), Malaysia (5\%), and Vietnam (3.3\%) [10].

The positive growth was supported by the entrepreneurs' movement in different parts of Indonesia, including Garut, which is known for its Dodol commodities, Leather Industry, Fragrant Root Industry, and Garutan Batik. However, this region is well known for producing quality local barbers. They show consistency in running the business, which is often referred to as "Asgar," or Asli Garut. In this regard, the two most famous areas include Banyuresmi Village and Bagendit Village, Banyuresmi Subdistrict-Garut [11].

The barbering business has become hereditary since the Dutch colonial era and became famous nationally during the DI/TII rebellion. At that time, there was a transfer of domicile, and therefore, men to open up barbershop business opportunities in various regions outside Garut [12]. This paper aims to determine the factors that influence the culture of entrepreneurship and whether it has an impact on the existing organizational climate.

\section{LITERATURE REVIEW}

Entrepreneurship is a market development that utilizes and maximizes the combination of innovation, resources, and technology in global competition $[3,13,14]$. In general, entrepreneurship has several features that are popular in the world. Entrepreneurship is said to be a culture in case interpretations, and perceptions of the society are the same, including knowledge, beliefs, arts, morals, customs, and information about its concept $[13,15,16]$.

According to previous studies, several factors shape entrepreneurial culture in various communities or societies. These include environmental factors education, economy, family structure, income level, and kinship relations [3,17-20]. Organizational climate is a phenomenon experienced by researchers in field practice arising from different conditions [21]. Organizational climate has a positive influence on the 
sustainability of an organization's competitiveness, an assertion supported by other studies [22-24]. There are several dimensions of organizational climate, including clarity, standards, responsibility, flexibility, rewards, and team commitment [25,26]. A healthy organizational climate is a long-term proposition. Every manager needs to take an asset approach through the climate. This means taking a long-term view of climate as an organizational asset [27].

\section{METHODS}

This study was conducted using a quantitative research approach and involved 77 barbers scattered in Banyuresmi and Bagendit villages, as well as in Garut Regency. The questionnaires were distributed to 77 barbers, while data was processed using SEM-PLS. A survey was conducted to prove the effect of entrepreneurial culture, which includes environmental factors, education, economy, family structure on the organizational climate of the barbershop business. Research variables can be seen on table 2 .

TABLE II. RESEARCH VARIABLES

\begin{tabular}{|c|c|c|}
\hline Variables & Indicators & Sources \\
\hline \multirow{4}{*}{$\begin{array}{l}\text { Entrepreneurial } \\
\text { Culture }(\mathrm{X})\end{array}$} & Family Structure (X1) & \multirow[t]{4}{*}[17,18,28,20,3]{} \\
\hline & Economy (X2) & \\
\hline & Environment Factor (X3) & \\
\hline & Education (X4) & \\
\hline \multirow{6}{*}{$\begin{array}{l}\text { Organizational } \\
\text { Climate (Y) }\end{array}$} & Clarity (Y1) & \multirow[t]{6}{*}[26,29]{} \\
\hline & Standards (Y2) & \\
\hline & Team Commitment (Y3) & \\
\hline & Flexibility (X4) & \\
\hline & Rewards (Y5) & \\
\hline & Responsibility (X6) & \\
\hline
\end{tabular}

\section{RESULTS AND DISCUSSION}

To determine the process of analyzing the influence of entrepreneurial culture through barbershop organization climate, data is processed using smartPLS software. The testing using this PLS is carried out in two steps, the assessment measurement or outer and structural assessment or inner models. There is a bootstrapping method that may duplicate randomly with smartPLS to eradicate abnormalities. According to the data and the analysis result by SmartPLS. The PLS Algorithm results show the calculation outcome of the convergent validity of the measurement model with its indicators. The indicator used can be reliable if the loading value is above 0.70 . The results of the output correlation between indicators and constructs are shown in the following table 3 .
TABLE III. OUTER LOADINGS MATRIX

\begin{tabular}{|l|l|l|}
\hline & Entrepreneurial Culture & Organizational Climate \\
\hline $\mathrm{X} 1$ & 0.944 & \\
\hline $\mathrm{X} 2$ & 0.952 & \\
\hline $\mathrm{X} 3$ & 0.447 & \\
\hline $\mathrm{X} 4$ & 0.506 & \\
\hline Y1 & & 0.941 \\
\hline Y2 & & 0.929 \\
\hline Y3 & 0.398 \\
\hline Y4 & & 0.551 \\
\hline Y5 & & 0.744 \\
\hline Y6 & \multicolumn{2}{c}{ Source: processed data } \\
\hline
\end{tabular}

Based on the outer loading matrix, there are several indicators with a factor loading value $<0.70$, hence not reliable. These indicators include Environmental Factor (X3), Education (X4), Team Commitment (Y3), and Flexibility (Y4). Unreliable indicators are removed from the model to fulfill the convergent validity since all loading factors are more than 0.70 .

To determine the value of cross loading between indicators with their constructs, an analysis was conducted by looking at Discriminant Validity on SmartPLS. The table 4 following are the results.

TABLE IV. CONSTRUCT RELIABILITY AND VALIDITY MATRIX

\begin{tabular}{|c|l|l|l|l|}
\hline & $\begin{array}{c}\text { Cronbach's } \\
\text { Alpha }\end{array}$ & Rho_A & $\begin{array}{l}\text { Composite } \\
\text { Reliability }\end{array}$ & $\begin{array}{c}\text { Average } \\
\text { Variance } \\
\text { Extracted }\end{array}$ \\
\hline $\begin{array}{c}\text { Entrepreneurial } \\
\text { Culture }\end{array}$ & 0.724 & 0.900 & 0.823 & 0.563 \\
\hline $\begin{array}{c}\text { Organizational } \\
\text { Climate }\end{array}$ & 0.856 & 0.944 & 0.896 & 0.609 \\
\hline
\end{tabular}

Source: processed dat

Determining whether a variable or the construct fulfills the validity score involves looking at the score of Average Variance Extracted (AVE). Ideally, the required score needs to be higher than 0.5 . The calculation results in Figure 3 show Entrepreneurial Culture and organizational climate have scores of 0.563 and 0.609 , respectively. Therefore, all the variables used are valid because they meet the requirements of AVE value $>0.50$

Assessing the reliability test used in the model involved measuring two aspects, composite reliability, and Cronbach's Alpha. Based on the measurement results in Figure 3, the entrepreneurial culture and organizational climate scored more than 0.70 , and therefore, all variables have good reliability. Furthermore, testing is carried out for structural models (inner models) by examining the R-Square score, which is a test of the Goodness-fit model, can be seen on table 5 bellow.

TABLE V. R SQUARE

\begin{tabular}{|l|l|l|}
\hline & R Square & R Square Adjusted \\
\hline Organizational Climate & 0.903 & 0.900 \\
\hline
\end{tabular}

Source: processed dat 
The test model of the influence of entrepreneurial culture on the barbershop business climate has an R-Square score of 0.903. This means that Entrepreneurial Culture explains Organizational Climate variability by $90 \%$, while other untested variables determine $10 \%$. The significance of entrepreneurial culture on the organizational climate of barbershop can be measured using the coefficient and the statistical significance score $t$. The first bootstrapping method is performed using the PLS model to produce the following figure. Additionally, bootstrapping generates the data shown in the following table 6 .

\section{TABLE VI. PATH COEFFICIENTS MatRix}

\begin{tabular}{|c|c|c|c|c|c|}
\hline $\begin{array}{l}\text { Mean, } \\
\text { STDEV, } \\
\text { T-Values, } \\
\text { P-Values }\end{array}$ & $\begin{array}{c}\text { Original } \\
\text { Sample } \\
\text { (O) }\end{array}$ & $\begin{array}{c}\text { Sample } \\
\text { Mean } \\
\text { (M) }\end{array}$ & $\begin{array}{l}\text { Standard } \\
\text { Deviation } \\
\text { (STDEV) }\end{array}$ & $\begin{array}{l}\text { T Statistics } \\
(\mid \text { O/STDEV } \mid)\end{array}$ & $\begin{array}{c}\mathbf{P} \\
\text { Values }\end{array}$ \\
\hline $\begin{array}{l}\text { Entrepren } \\
\text { eurial } \\
\text { Culture -> } \\
\text { Organizati } \\
\text { onal } \\
\text { Climate }\end{array}$ & 0.976 & 0.977 & 0.005 & 189.063 & 0.000 \\
\hline
\end{tabular}

Based on Figure 6, the score of the Original sample on the relationship between the entrepreneurial Culture and Organizational Climate is 0.976. This means Entrepreneurial Culture has a positive influence on Organizational Climate. From these results, the higher the score of entrepreneurial culture in the Cukur Garut kampong village, the higher the organizational climate in the barbershop business. This is in line with the findings of several previous studies $[1,18,30]$ Furthermore, the score of $\mathrm{t}$ statistic is 189,063 greater than $\mathrm{t}$ table 1.96, meaning that entrepreneurial culture significantly influences the organizational climate of the barbershop business in Garut Barber Village.

\section{CONCLUSION}

Entrepreneurial culture in Garut Barber Village is formed from several aspects, including family factors. This is evident from the results of the research in which 70 respondents out of 77 individuals became barbers because the family structure has historically been a barber before. Moreover, an economic factor also plays a significant role in forming an entrepreneurial culture. The income earned from this entrepreneurship attracts young people in the village to become barbers. Most of them gain motivation by looking at the work of their colleagues. Also, a strong and significant entrepreneurial culture has an impact on the formation of organizational climate in a barbershop. The climate of the organization is characterized by clarity, standards, rewards, and responsibility factors. The most dominant factor of the organizational climate is the strong value of responsibility in barbershop businesses. There is a connection between strong economic needs and the demands of society today.

\section{REFERENCES}

[1] N.A. Hamdani, G.A.F. Maulani, and A.A. Muharam, "Entrepreneurial Culture in the Village of the Barbers, Garut, Indonesia," Int. J. Eng. Adv. Technol., vol. 8, no. 5C, pp. 685-687, 2019.

[2] C. Chaşovschi, O. Bordeianu, and D. Clipa, "Entrepreneurial Culture in Transition Economies. The case of Romania and Republic of Moldova," Procedia Econ. Financ., vol. 15, no. 14, pp. 1507-1514, 2014.

[3] L. Duman, A. Bedük, A.S. Köylüoğlu, and K. Ay, "Entrepreneurship Culture at SMEs: A Case Study in Konya," Procedia - Soc. Behav. Sci., vol. 207, pp. 492-501, 2015.

[4] G.A.F. Maulani and N.A. Hamdani, "The Influence of Information Technology and Organizational Climate on the Competitiveness of Private Universities in Indonesia," Int. J. Recent Technol. Eng., vol. 8, no. 1S, pp. 142-145, 2019.

[5] N.A. Hamdani, A. Solihat, and G.A.F. Maulani, "The Influence of Information Technology and Co-Creation on Handicraft SME Business Performance,” Int. J. Recent Technol. Eng., vol. 8, no. 1S, pp. 151-154, 2019.

[6] N.E. Popescu, "Entrepreneurship and SMEs Innovation in Romania," Procedia Econ. Financ., vol. 16, no. May, pp. 512-520, 2014.

[7] N.A. Hamdani and G.A.F. Maulani, "The Influence Information Technology Capabilities and Differentiation on the Competitiveness of Online Culinary SMEs,” Int. J. Recent Technol. Eng., vol. 8, no. 1S, pp. 146-150, 2019.

[8] Badan Pusat Statistik, Statistik Indonesia 2019. Jakarta: Badan Pusat Statistik Indonesia, 2019.

[9] T. Siregar, "Jumlah Wirausaha di Indonesia Tembus 8 Juta Jiwa," http://rri.co.id, 2019. [Online]. Retrieved from http://rri.co.id/post/berita/651422/ekonomi/jumlah_wirausaha_di_indone sia_tembus_8_juta_jiwa.html. [Accessed: 28-Dec-2019].

[10] W.P "Jumlah Pengusaha di Indonesia Meningkat, Tapi...," koinworks.com, 2018. [Online]. Retrieved from https://koinworks.com/blog/jumlah-pengusaha-di-indonesia-meningkat/.

[11] J. Supriadin, "Banyuresmi, Kampung Sekolah Tukang Cukur Andal Indonesia," www.liputan6.com, 2017. [Online]. Retrieve from https://www.liputan6.com/regional/read/2968462/banyuresmi-kampungsekolah-tukang-cukur-andal-indonesia.

[12] I. Teguh, “Ada Apa di Balik Banyaknya Juru Pangkas Rambut Asli Garut?,” tirto.id, 2019. [Online]. Retrieved from https://tirto.id/ada-apadi-balik-banyaknya-juru-pangkas-rambut-asli-garut-deL7.

[13] T.K. Şahin and T. Asunakutlu, "Entrepreneurship in a Cultural Context: A Research on Turks in Bulgaria," Procedia - Soc. Behav. Sci., vol. 150, pp. 851-861, 2014.

[14] A. Turró, D. Urbano, and M. Peris-Ortiz, "Culture and innovation: The moderating effect of cultural values on corporate entrepreneurship," Technol. Forecast. Soc. Change, vol. 88, pp. 360-369, 2014.

[15] S.J. Peterson and S.M. Lee, "Culture , Entrepreneurial Orientation , and Global Competitiveness," J. World Bus., vol. 35, no. 4, pp. 401-416, 2000 .

[16] M. Stuetzer, "Industry structure, entrepreneurship, and culture: An empirical analysis using historical coalfields," Eur. Econ. Rev., vol. 86, pp. 52-72, 2016.

[17] I.R. Mirzanti, T.M. Simatupang, and D. Larso, "Mapping on Entrepreneurship Policy in Indonesia," Procedia - Soc. Behav. Sci., vol. 169, no. August 2014, pp. 346-353, 2015.

[18] C. Seaman, R. Bent, and A. Unis, "Family entrepreneurship culture, entrepreneurial intent, futures and foresight in Scottish Pakistani communities," Futures, vol. 75, pp. 83-91, 2016.

[19] A.D. Zaridis and D.T. Mousiolis, "Entrepreneurship and SME's Organizational Structure. Elements of a Successful Business," Procedia Soc. Behav. Sci., vol. 148, pp. 463-467, 2014. 
[20] A. Majocchi and M. Presutti, "Industrial clusters, entrepreneurial culture and the social environment: The effects on FDI distribution," Int. Bus. Rev., vol. 18 , no. 1, pp. 76-88, 2009.

[21] M.A. West, "Organizational Climate,” Int. Encycl. Soc. Behav. Sci., vol. 16, pp. 322-326, 2015.

[22] J.C. Sarros, B.K. Cooper, and J. C. Santora, "Through Transformational Leadership and Organizational Culture,” J. Leadersh. Organ. Stud., vol. 15 , no. 2, pp. 145-158, 2008.

[23] G. Ceyda and P. Sevinc, "Determination of High Schools Organizational Climate,” Procedia - Soc. Behav. Sci., vol. 46, pp. 2947-2950, 2012.

[24] P.Y. Permarupan, R. Ahmad, R. Suzana, and R. Kasim, "The Impact of Organizational Climate on Employee, s Work Passion and Organizational Commitment,” Procedia - Soc. Behav. Sci., vol. 107, pp. 88-95, 2013.

[25] H. Sulistyo and Siyamtinah, "Innovation capability of SMEs through entrepreneurship, marketing capability, relational capital and empowerment," Asia Pacific Manag. Rev., vol. 21, no. 4, pp. 196-203, 2016

[26] A.A. Waspodo and L. Minadaniati, "Pengaruh Kepuasan Kerja Dan Iklim Organisasi Terhadap Organizational Citizenship Behavior ( Ocb ) Karyawan Pada PT. Trubus Swadaya,” J. Ris. Manaj. Sains Indones., vol. 3, no. 1, pp. 1-16, 2012.

[27] K. Haritha and S.E.V Subrahmanyam, "Organisational Climate: An Empirical Investigation in PennaCement Industries Limited ( PCIL )," Int. J. Bus. Manag. Invent., vol. 2, no. 12, pp. 12-20, 2013.

[28] R. Gavron, The entrepreneurial society. London: IPPR, 1998.

[29] R. Sulistiyani and W. Harwiki, "How SMEs Build Innovation Capability Based on Knowledge Sharing Behavior? Phenomenological Approach," Procedia - Soc. Behav. Sci., vol. 219, pp. 741-747, 2016.

[30] A.D. Cruz, E. Hamilton, and S.L. Jack, "Understanding entrepreneurial cultures in family businesses: A study of family entrepreneurial teams in Honduras,” J. Fam. Bus. Strateg., vol. 3, no. 3, pp. 147-161, 2012. 